\title{
QTLs for seedling traits under salinity stress in hexaploid wheat
}

\section{Yongzhe $\operatorname{Ren}^{1 *} \odot$ Yanhua $\mathrm{Xu}^{1,2} \odot$ Wan $\mathrm{Teng}^{3}$ Bin $\mathrm{Li}^{3}$ Tongbao $\mathrm{Lin}^{1}$}

\footnotetext{
${ }^{1}$ College of Agronomy/State Key Laboratory of Wheat and Maize Crop Science/Collaborative Innovation Center of Henan Grain Crops, Henan Agricultural University, 450002, Zhengzhou, China. E-mail: yongzheren66@163.com. "Corresponding author.

${ }^{2}$ Shangqiu Normal University, Shangqiu, China.

${ }^{3}$ State Key Laboratory for Plant Cell and Chromosome Engineering, Institute of Genetics and Developmental Sciences, Chinese Academy of Sciences, Beijing, China.
}

\begin{abstract}
Soil salinity limits agricultural production and is a major obstacle for increasing crop yield. Common wheat is one of the most important crops with allohexaploid characteristic and a highly complex genome. QTL mapping is a useful way to identify genes for quantitative traits such as salinity tolerance in hexaploid wheat. In the present study, a hydroponic trial was carried out to identify quantitative trait loci (QTLS) associated with salinity tolerance of wheat under $150 \mathrm{mM} \mathrm{NaCl} \mathrm{concentration} \mathrm{using} \mathrm{a} \mathrm{recombinant} \mathrm{inbred} \mathrm{line} \mathrm{population} \mathrm{(Xiaoyan}$ $54 \times$ Jing 411). Values of wheat seedling traits including maximum root length (MRL), root dry weight (RDW), shoot dry weight (SDW), total dry weight (TDW) and the ratio of TDW of wheat plants between salt stress and control (TDWR) were evaluated or calculated. A total of $19 Q T L s$ for five traits were detected through composite interval mapping method by using QTL Cartographer version 2.5 under normal and salt stress conditions. These QTLs distributed on 12 chromosomes explained the percentage of phenotypic variation by individual QTL varying from 7.9\% to $19.0 \%$. Among them, 11 and six QTLs were detected under normal and salt stress conditions, respectively and two QTLs were detected for TDWR. Some salt tolerance related loci may be pleiotropic. Chromosome 1A, 3A and 7A may harbor crucial candidate genes associated with wheat salt tolerance. Our results would be helpful for the marker assisted selection to breed wheat varieties with improved salt tolerance. Key words: Triticum aestivum L., salinity stress, quantitative trait locus (QTL), marker assisted selection.
\end{abstract}

Caracterização de QTLs por traços de sementes sob o estresse de salinidade em trigo Hexaploid

RESUMO: A salinidade do solo limita a produção agrícola. O trigo mole é uma das culturas mais importantes com característica allohexaploid e genoma altamente complexo. O mapeamento QTL é uma maneira muito útil de identificar genes para traços quantitativos, como a tolerância à salinidade em trigo hexaplóide. No presente estudo realizou-se um ensaio hidropónico para identificar locos de traços quantitativos (QTLs) associados à tolerância à salinidade do trigo sob concentração de NaCl $150 \mathrm{mM}$, usando uma população de linhagem consanguíneo recombinante (Xiaoyan $54 \times$ Jing 411). Os valores dos traços de mudas de trigo, incluindo comprimento máximo da raiz (MRL), peso seco da raiz $(R D W)$, ponha o peso seco $(S D W)$, peso seco total (TDW) e a proporção das plantas de trigo TDW entre o estresse salgado e o controle (TDWR), foram avaliados ou calculados. Um total de 19QTLs para cinco traços foram detectados através do método de mapeamento de intervalo composto usando a versão 2.5 do cartógrafo QTL sob condições normais e de estresse salino. Estes QTLs distribuidos em 12 cromossomos explicaram a porcentagem de variação fenotípica por QTL individual variando de 7,9\% a 19,0\%. Entre eles, foram detectados 11 e 6 QTLs em condições de estresse normal e sal, respectivamente, e dois QTLs foram detectados para TDWR. Cromossoma 1A, 3 A e $7 A$ podem conter genes que são candidatos cruciais associados à tolerância ao sal de trigo. Nossos resultados seriam úteis para a seleção assistida por marcadores para produzir variedades de trigo com tolerância salina melhorada.

Palavras-chave: Triticum aestivum L., Stress de salinidade, QTL, Seleção assistida por marcador.

\section{INTRODUCTION}

Dryland salinity is a major limitation to crop production. About $20 \%$ of irrigated agricultural land in the world is affected by salinity (BOYER, 1982; FLOWERS et al., 1995). Soil salinity inhibits plant growth for not only osmotic stress but ionexcess stress. The presence of salt in the soil solution reduces the ability of plants to take up water, and then affects growth. This is the osmotic effect of salinity. Moreover, uptake excessive amounts of salt will eventually injure cells in the transpiring leaves and this may further reduce growth. This is the ionexcess effect of salinity (MUNNS, 1993; MUNNS, 2006). To survive, plants have evolved complex salt tolerance mechanisms (ZHU et al., 2002; HANIN et 
al., 2016). For example, the salt overly sensitive (SOS) pathway of salt tolerance is crucial for maintaining ion homeostasis under salt stress in model plant Arabidopsis. SOS pathway was also more active in salt tolerant cultivar PI365967 than in salt sensitive cultivar in tomato indicating that SOS pathway may be conserved across diverse plant species. Besides, salicylic acid (SA), abscisic acid (ABA), brassinosteroids (BRs) pathway and detoxification system may also be involved in salt perception or salt responses (KRISHNA et al., 2003; MARTINEZATIENZA et al., 2007; SUN et al., 2010; SUN et al., 2015; CHEN et al., 2017).

Wheat is one of the most important food crops. Improving salt tolerance of wheat is needed to sustain food production in many regions in the world. To exploit variation in salt tolerance of wheat, large international collections have been screened in hydroponic or sand culture (KINGSBURY et al., 1984; SAYED, 1985; JAFARI-SHABESTARI et al., 1995). These researches laid a solid foundation for breeding wheat varieties with improved salt tolerance and provided us with research materials for probing into the mechanisms of wheat salt tolerance. In recent years, genome-wide transcriptomic and proteomic analysis for identification of saltresponsive genes in common wheat provided many useful clues (KAWAURA et al., 2008; GUO et al., 2012; CAPRIOTTI et al., 2014; GOYAL et al., 2016; JIANG et al., 2017). The differential expressed proteins/genes were involved primarily in carbon metabolism, detoxification and defense, chaperon and signal transduction. A number of salt tolerant related genes (FEKI et al., 2014; MAKHLOUFI et al., 2014; SUN et al., 2015; TOUNSI et al., 2016; GOYAL et al., 2016; CHEN et al., 2017) and QTLs (MEGAN et al., 2004; HUANG et al., 2006; WU et al., 2007; GENC et al., 2010; REN et al., 2012a; XU et al., 2013; MASOUDI et al., 2015; TOUNSI et al., 2016; OYIGA et al., 2017) have been identified in wheat in recent years. These provided useful information for genetic improvement of salt tolerance in wheat. However, for the intricate character of wheat salt tolerance, the underlying genetic basis was still unclear. Therefore, further exploiting QTLs that contribute to natural variation in salt tolerance would be helpful in understanding the mechanisms of wheat salt tolerance.

In wheat, salt tolerance is associated with low rates of transport of $\mathrm{Na}^{+}$to shoots and high selectivity for $\mathrm{K}^{+}$over $\mathrm{Na}^{+}$which were controlled by Knal located on chromosome 4D (GORHAM et al., 1987; GORHAM et al., 1990; DUBCOVSKY et al., 1996). Correlations between grain yield and $\mathrm{Na}^{+}$exclusion from leaves, along with the associated enhanced $\mathrm{K}^{+} / \mathrm{Na}^{+}$discrimination, have also been shown in wheat (CHHIPA et al., 1995; ASHRAF et al., 1997; XU et al., 2013; MASOUDI et al., 2015). Growth performance of seedlings of one specific wheat cultivar grown under salt stress can reflect its salt tolerance to a great extent. Root length, root fresh and dry weights, and shoot fresh and dry weights of wheat seedlings are associated with salt tolerance and could be used as selection criteria in wheat (SHAHZAD et al., 2012). In this paper, we mapped QTLs for seedling traits under normal and salt stress conditions using a recombinant inbred line (RIL) population derived from two Chinese wheat varieties Xiaoyan 54 and Jing 411. These results may provide useful information for molecular design of wheat varieties with improved salt tolerance.

\section{MATERIALS AND METHODS}

One recombinant inbred line (RIL) population was used in this study. The RIL population contained 142 RILs derived from two Chinese winter wheat varieties Xiaoyan 54 and Jing 411.

Hydroponic culture was used to investigate the seedling traits of wheat. Methods for seed sterilization, germination and the growth conditions of wheat plants were described previously (REN et al., 2012b). The growth chamber was set at $22^{\circ} \mathrm{C}$ in the day time and $18^{\circ} \mathrm{C}$ in the night time, $60 \%$ relative humidity and a 15 -hour day length. The seedling traits of the "Xiaoyan $54 \times$ Jing 411 " RIL population were investigated after these lines were grown in nutrition solution in the growth chamber for 25 days under normal $(\mathrm{CK})$ and salt stress (ST, $150 \mathrm{mM} \mathrm{NaCl}$ ) conditions. The maximum root length (MRL) of plant roots were measured using a ruler and then the shoot dry weight (SDW), root dry weight (RDW) and total dry weight (TDW) were measured after oven-drying at $80^{\circ} \mathrm{C}$ for $48 \mathrm{~h}$. The ratio of TDW (TDWR, ST/CK) of each line was also calculated.

The genetic map of the "Xiaoyan $54 \times$ Jing 411" RIL population was described by REN et al., (2012b). Detection of QTLs for wheat seedling traits under normal and salt stress conditions in this RIL population was conducted by composite interval mapping (ZENG, 1994). Analyses of QTL location, additive effect and 95\% confidence intervals of QTLs were performed using WinQTLCart 2.5 software (WANG et al., 2012). The stand model was employed and the parameters of forward regression analysis 
were set according to the method described by SU et al. (2009) and WANG et al. (2012). In brief, the walk speed and window size were set as $2 \mathrm{cM}$ and $10 \mathrm{~cm}$, respectively, with five control markers. Phenotypic variation explained by a single QTL was determined by the square of the partial correlation coefficient $\left(R^{2}\right)$. Threshold of LOD value for QTL detection was set as 3.0.

\section{RESULTS}

\section{Evaluation of phenotypes}

We measured root dry weight (RDW), maximum root length (MRL), shoot dry weight (SDW) and total dry weight (TDW) under normal (CK) and salt stress (ST) conditions. Under CK condition, the male parent Jing 411 had significant higher RDW, SDW and TDW than the female parent Xiaoyan 54, but it had shorter MRL than Xiaoyan 54 (Table 1). Salt stress significantly reduced the values of all these four traits in Xiaoyan 54 and Jing 411 compared to CK treatment. Jing 411 and Xiaoyan 54 had similar RDW and MRL, but Jing 411 had higher SDW and TDW than Xiaoyan 54 under ST condition (Table 1). These two parents also had similar relative TDW (TDWR, the ratio of TDW under ST and CK conditions), indicating that the plant growth of these two parents had similar sensitivity to salt stress.

The RIL lines showed large variations in all the investigated traits (Table 1). There existed RILs with values that were higher or lower than both parents among all these traits, indicating potential transgressive variations and the presence of positive and negative alleles in both parents.

\section{QTLs Identification}

We totally detected three QTLs for RDW, three for MRL, five for SDW, six for TDW and two for TDWR. These 19QTLs located on 12 chromosomes, and the percentage of phenotypic variation explained by individual QTL varied from $7.9 \%$ to $19.0 \%$ (Figure 1 and 2, Table 2).

We detected two and one QTLs for RDW under normal and $150 \mathrm{mM} \mathrm{NaCl}$ salt stress condition respectively. $q R D W . S T-4 A$, the QTL detected under ST condition located on chromosome 4A and explained $19.0 \%$ of phenotypic variation in RDW (Figure 1 and 2, Table 2).

One and two QTLs for MRL were detected under $\mathrm{CK}$ and ST conditions respectively (Figure 1 and 2, Table 2). $q M R L . C K-2 B$ for MRL were detected in $C K$ which located on the short arm of chromosome 2B and the other two QTLs were detected under ST condition. qMRL.ST-4D located on chromosome 4D and explained $8.3 \%$ MRL variation. $q M R L . S T-6 B$ located on chromosome 6B and explained 16\% MRL variation (Table 2).

Four and one QTLs for SDW were detected under CK and ST conditions respectively. The only QTL for SDW detected under ST condition, qSDW.ST$7 A$, located on chromosome 7A and explained $12.4 \%$ SDW phenotypic variation (Figure 1 and 2, Table 2).

We detected four and two QTLs for TDW under CK and ST conditions respectively. (Figure 1 and 2, Table 2). The six QTLs for TDW explained phenotypic variations varying from $9.3 \%$ to $15.3 \%$. qTDW.ST-3A and $q T D W . S T-7 A$ were detected under ST condition and explained $12.3 \%$ and $12.0 \%$ TDW phenotypic variations respectively (Figure 1 and 2, Table 2).

We detected two QTLs for TDWR (Figure 1 and 2, Table 2). qTDWR-1A located on chromosome

Table - 1 Mean values and ranges for the investigated traits in the RIL population and their parents at seedling stage in this trial.

\begin{tabular}{|c|c|c|c|c|c|c|}
\hline \multirow{2}{*}{ Trait } & \multirow{2}{*}{ Treatment } & 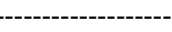 & --------------- & -------------- & ----- & -.---- \\
\hline & & Xiaoyan54 & Jing 411 & Mean \pm SD & Min. & Max. \\
\hline \multirow{2}{*}{ RDW } & CK & $9.5 \pm 0.8(a)$ & $11.7 \pm 0.8(b)$ & $11.8 \pm 3.3$ & 6.0 & 23.0 \\
\hline & $\mathrm{ST}$ & $8.0 \pm 1.6$ & $8.0 \pm 0.5$ & $10.1 \pm 2.8$ & 3.6 & 34.0 \\
\hline \multirow{2}{*}{ MRL } & CK & $26.4 \pm 0.8(\mathrm{~A})$ & $19.8 \pm 0.7(\mathrm{~B})$ & $23.2 \pm 4.8$ & 13.0 & 37.5 \\
\hline & ST & $16.5 \pm 0.5$ & $16.8 \pm 1.5$ & $15.6 \pm 2.2$ & 9.4 & 22.4 \\
\hline \multirow{2}{*}{ SDW } & $\mathrm{CK}$ & $61.2 \pm 1.5(\mathrm{~A})$ & $76.1 \pm 4.0(\mathrm{~B})$ & $71.9 \pm 17.3$ & 39.0 & 127.7 \\
\hline & ST & $41.2 \pm 1.2(\mathrm{a})$ & $52.4 \pm 3.4(b)$ & $42.4 \pm 8.2$ & 21.7 & 66.0 \\
\hline \multirow{2}{*}{ TDW } & CK & $70.7 \pm 2.2(\mathrm{a})$ & $87.9 \pm 3.1(b)$ & $83.7 \pm 19.9$ & 46.7 & 149.6 \\
\hline & ST & $49.2 \pm 1.6(a)$ & $60.4 \pm 2.9(b)$ & $52.5 \pm 9.8$ & 25.3 & 82.7 \\
\hline
\end{tabular}

RDW, root dry weight $\left(\mathrm{mg}\right.$ plant $\left.^{-1}\right)$; MRL, maximum root length $(\mathrm{cm})$; SDW, shoot dry weight $\left(\mathrm{mg} \mathrm{plant}^{-1}\right)$; TDW, total biomass dry weight $\left(\mathrm{mg} \mathrm{plant}^{-1}\right)$. Statistical difference between the two parents is indicated by different letters after the means. Lower case letters designate significance at $\mathrm{P}<0.05$. Capital letters designate significance at $\mathrm{P}<0.01$. 


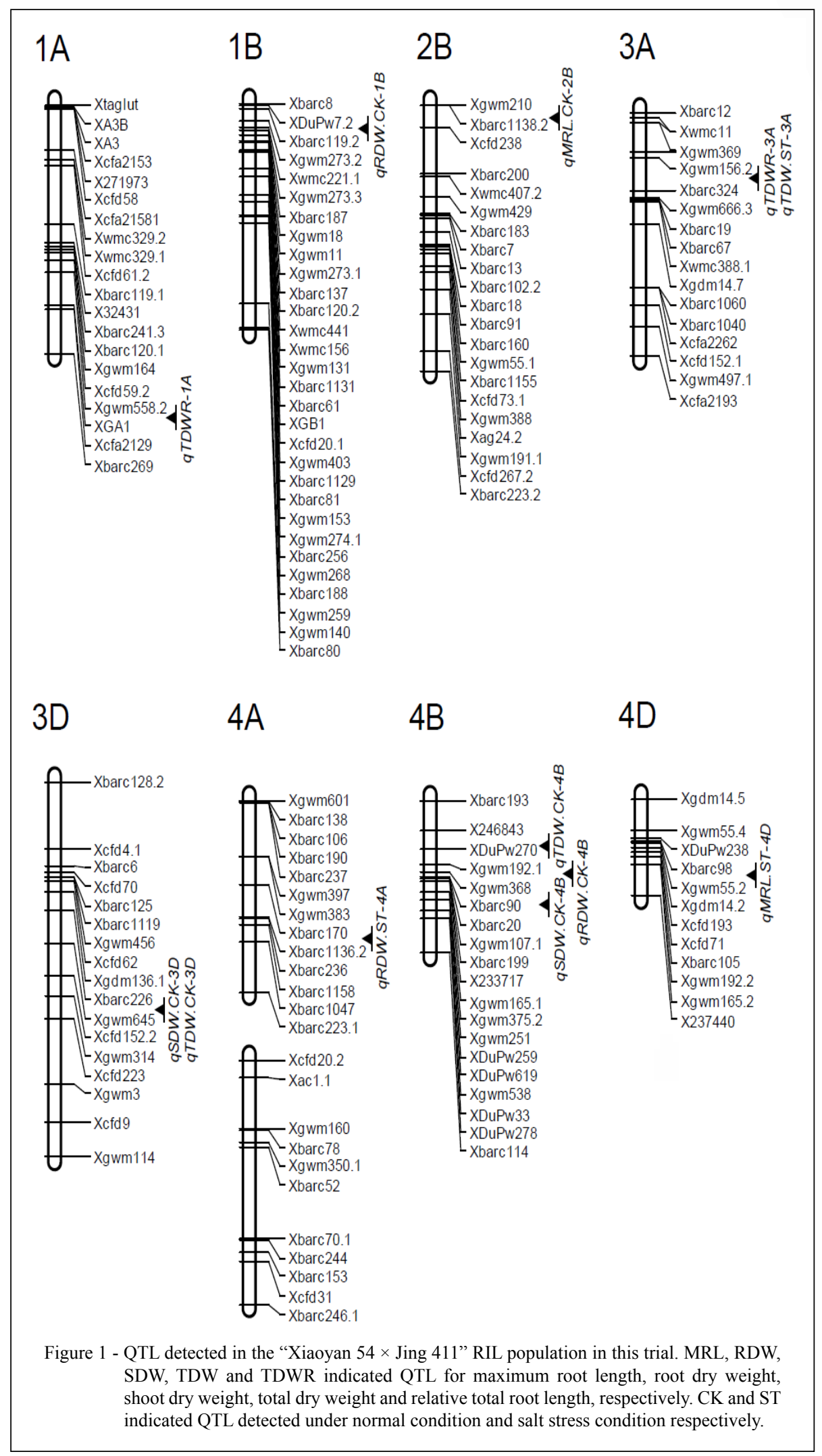

Ciência Rural, v.48, n.3, 2018. 


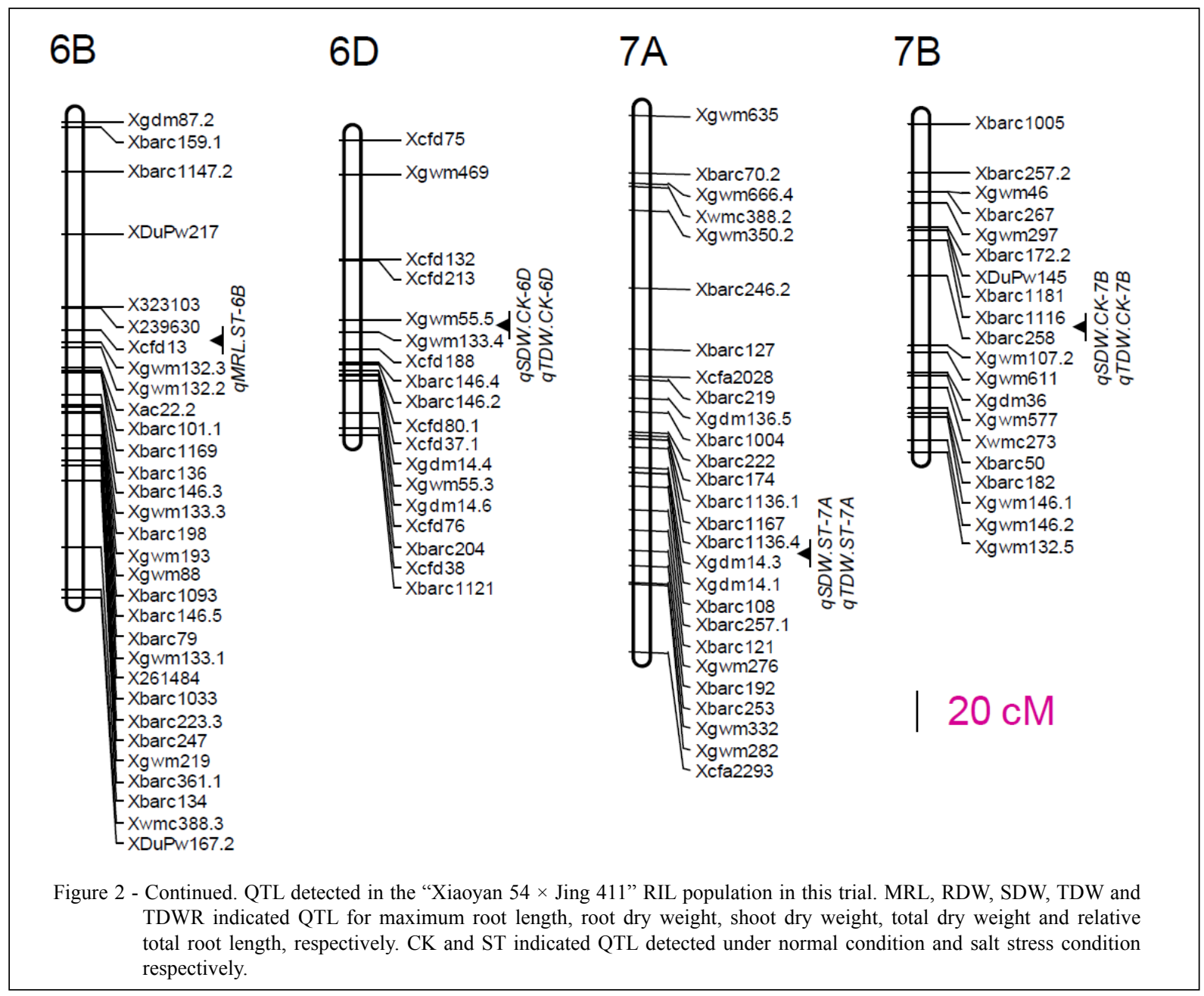

1A and explained $13.7 \%$ TDWR variation. the other QTL, qTDWR-3A, located on chromosome 3A and explained 15\% TDWR variation. (Table 2).

\section{DISCUSSION}

Although some single-gene effects for salinity tolerance have been identified in higher plants (for example AtNHXI and RAS1 in Arabidopsis (APSE et al., 1999; REN et al., 2010), OsNHX1 and $S K C 1$ in rice (FUKUDA et al., 1999; REN et al., 2005)), the tolerance of salinity is genetically and physiologically complex. Large international collections have been screened (KINGSBURY et al., 1984; SAYED, 1985; JAFARI-SHABESTARI et al., 1995), however, the application of salt-tolerant varieties to the improvement of cereal crops such as wheat remains hampered because of the quantitative nature of the genes involved. Identification of QTLs and some defined regions of chromosome are of crucial importance to enhance wheat salt tolerance. Markers closely associated with major QTLs for salt tolerance might be used for breeding programs in wheat using marker-assisted selection. QTL analyses for salt tolerance in wheat at seedling stage have been conducted in previous studies (MEGAN et al., 2004; HUANG et al., 2006; WU et al., 2007; GENC et al., 2010; REN et al., 2012a; XU et al., 2013; MASOUDI et al., 2015; OYIGA et al., 2017). However, these genes and/or QTLs are not sufficient for understanding the genetic basis and the genetic improvement of salt tolerance in wheat. To further exploit QTLs for wheat salt tolerance, we evaluated the seedling traits of a RIL population under normal and salinity stress conditions in this paper. We found that there exist no significant differences of RDW and MRL between Xiaoyan 54 
Table 2 - QTLs detected in this trial using the "Xiaoyan 54×Jing 411" RIL population.

\begin{tabular}{|c|c|c|c|c|c|c|c|}
\hline Trait & Treat-ment & QTL & $\mathrm{Chr}^{\mathrm{a}}$ & Marker interval $^{\mathrm{b}}$ & $\mathrm{LOD}^{\mathrm{c}}$ & $R^{2} \times 100$ & Additive $^{\mathrm{d}}$ \\
\hline \multirow{3}{*}{ RDW } & $\mathrm{CK}$ & $q R D W . C K-1 B$ & 1B & $\underline{X D u P w 7.2-X b a r c 119.2}$ & 3.4 & 7.9 & 1.2 \\
\hline & $\mathrm{CK}$ & $q R D W . C K-4 B$ & $4 \mathrm{~B}$ & Xgwm192.1-Xgwm368 & 4.5 & 11.6 & -1.4 \\
\hline & ST & $q R D W . S T-4 A$ & $4 \mathrm{~A}$ & Xbarc170-Xbarc1136.2 & 3.3 & 19.0 & 0.5 \\
\hline \multirow{3}{*}{ MRL } & $\mathrm{CK}$ & $q M R L . C K-2 B$ & $2 \mathrm{~B}$ & Xbarc1138.2-Xcfd238 & 5.1 & 15.2 & 2.1 \\
\hline & ST & $q M R L . S T-4 D$ & $4 \mathrm{D}$ & $\underline{X b a r c 98-X g w m 55.2}$ & 3.0 & 8.3 & 0.4 \\
\hline & ST & $q M R L . S T-6 B$ & $6 \mathrm{~B}$ & $\underline{X 239630-X c f d 13}$ & 4.5 & 16.0 & -0.6 \\
\hline \multirow{5}{*}{ SDW } & CK & $q S D W . C K-3 D$ & $3 \mathrm{D}$ & Xbarc226-Xgwm645 & 3.2 & 13.7 & 7.3 \\
\hline & $\mathrm{CK}$ & $q S D W . C K-4 B$ & 4B & $\underline{X b a r c 90}-\underline{X b a r c 20}$ & 4.2 & 9.8 & -6.2 \\
\hline & CK & $q S D W . C K-6 D$ & $6 \mathrm{D}$ & Xgwm55.5-Xgwm133.4 & 3.7 & 9.4 & -6.1 \\
\hline & $\mathrm{CK}$ & $q S D W . C K-7 B$ & $7 \mathrm{~B}$ & Xbarc1116-Xbarc258 & 3.4 & 12.1 & -6.9 \\
\hline & ST & $q S D W . S T-7 A$ & $7 \mathrm{~A}$ & Xbarc1136.4-Xgdm14.3 & 3.6 & 12.4 & -1.7 \\
\hline \multirow{6}{*}{ TDW } & $\mathrm{CK}$ & $q T D W . C K-3 D$ & $3 \mathrm{D}$ & $\underline{X b a r c 226-X g w m 645}$ & 3.7 & 15.3 & 8.8 \\
\hline & $\mathrm{CK}$ & $q T D W . C K-4 B$ & $4 \mathrm{~B}$ & $X \overline{D u P w 270}-X g w m 192.1$ & 3.1 & 9.3 & -7.0 \\
\hline & $\mathrm{CK}$ & $q T D W . C K-6 D$ & $6 \mathrm{D}$ & $\underline{X g w m 55.5-X g w m 133.4}$ & 4.1 & 10.2 & -7.2 \\
\hline & $\mathrm{CK}$ & $q T D W . C K-7 B$ & $7 \mathrm{~B}$ & Xbarc1116-Xbarc258 & 3.3 & 9.5 & -7.0 \\
\hline & ST & $q T D W . S T-3 A$ & $3 \mathrm{~A}$ & Xgwm156.2-Xbarc 324 & 3.51 & 12.3 & -2.1 \\
\hline & ST & qTDW.ST-7A & $7 \mathrm{~A}$ & Xbarc1136.4-Xgdm14.3 & 3.8 & 12.0 & -2.0 \\
\hline \multirow{2}{*}{ TDWR } & $\mathrm{ST} / \mathrm{CK}$ & $q T D W R-1 A$ & $1 \mathrm{~A}$ & Xgwm558.2-XGluA1 & 3.6 & 13.7 & 0.044 \\
\hline & $\mathrm{ST} / \mathrm{CK}$ & $q T D W R-3 A$ & $3 \mathrm{~A}$ & Xgwm 156.2-Xbarc324 & 4.3 & 15.0 & -0.038 \\
\hline
\end{tabular}

${ }^{\mathrm{a}} \mathrm{Chr}$ means chromosome name. ${ }^{\mathrm{b}}$ Markers underlined were the nearest marker to the QTL. ${ }^{\mathrm{c}}$ LOD means Logarithm of odds. ${ }^{\mathrm{d}}$ Additive effects, a positive sign means that positive allele comes from the parent Xiaoyan 54, while a negative sign means positive allele comes from the parent Jing 411.

and Jing411, but Jing 411 had higher SDW and TDW than Xiaoyan 54 under under $150 \mathrm{mM}$ salt stress condition. The RDW, MRL, SDW and TDW of the RIL population were significantly decreased under salt stress condition comparing to those of under normal condition (Table 1, 2), which is in consistence with previous study (WU et al., 2007; REN et al., 2012a; TOUNSI et al., 2016).

In total, we detected 11 and six QTLs under normal and salt stress conditions respectively and two QTLs for TDWR (Table 2). These 19 QTLs explained phenotypic variations varying from $7.9 \%$ to $19.0 \%$ (Table 2). The locus for MRL on chromosome 2B, which tightly linked with SSR marker Xbarc1138, explained 15.2\% MRL phenotypic variation (Figure 1 and 2, Table 2). In fact, this locus has been reported controlling multi-root morphologic parameters and a number of QTLs for yield component (explained $19.1 \%$ and $17.3 \%$ of phenotypic variations in grain weight per ear and grain number per ear, respectively) (REN et al., 2012b; HAI et al., 2008). However, we did not detect any QTLs for root traits in this chromosomal region under ST condition, indicated that the expression of this locus is inhibited and very sensitive to salt stress. Actually this QTL has been proved to be involved in brassinosteroids (BRs) signaling pathway (HE et al., 2014) and BRs is also known to confer salt stress tolerance (KRISHNA et al., 2003; ZHU et al., 2016). The qTDWR-3A located on chromosome 3A between SSR marker Xgwm156.2 and Xbarc324, and explained 15.0\% TDWR phenotypic variation. We found that some chromosomal regions governed more than one trait under salt stress condition. For example, qTDW.ST$3 A$ and $q T D W R-3 A$ were mapped in the same marker interval (Xgwm156.2-Xbarc324) on chromosome 3A. The marker interval Xbarc1136.4- Xgdm14.3 on chromosome 7A also located two QTLs ( $q S D W . S T$ $7 A$ and $q T D W . S T-7 A)$. These salt-tolerance related loci may be pleiotropic.

We found that some QTLs detected in this study were tightly linked or coincided with previously reported salt tolerant QTLs in wheat. qTDWR-1A was located on chromosome $1 \mathrm{~A}$ and tightly linked with SSR marker Xgwm558. Actually, this chromosomal region has been reported harboring two QTLs for salt tolerance, named $Q T d w-1 A$ and QSkn-1A (controlling Shoot $\mathrm{K}^{+} / \mathrm{Na}^{+}$concentration ratio), which also linked with SSR marker $X g w m 558$ on chromosome 1A. qTDWR-3A and qTDW.ST-3A 
were located between SSR marker Xgwm156.2 and $X$ barc 324 on chromosome $3 \mathrm{~A}$ and coincided with previously reported $Q T D W-3 A$ and $Q S k n-3 A$ (XU et al., 2012). Genc had proved that QTLs for $\mathrm{Na}^{+}$ exclusion was associated with an increase $(10 \%)$ in seedling biomass. Of the five QTLs identified for $\mathrm{Na}^{+}$exclusion in the literature, two were colocated with seedling biomass (GENC et al., 2010). SHAHZAD also verified that the biomass of wheat seedlings could be used as selection criteria in salt tolerance (SHAHZAD et al., 2012). Taken together, the clustering of $q T D W R-3 A$ and $q T D W . S T-3 A$, and coinciding with previously reported QTL for $\mathrm{K}^{+} / \mathrm{Na}^{+}$ concentration ratio indicated that this chromosomal region may harbor crucial salt-tolerance genes. The QTLs detected repeatedly in different trials described above may facilitate MAS of wheat salt tolerance.

\section{CONCLUSION}

We identified a total of 19QTLs for wheat seedling traits, of which 11 were detected under normal condition and six under salt stress condition. The other two QTLs controlled TDWR. Some salt-tolerance related loci may be pleiotropic. Chromosome 1A, $3 \mathrm{~A}$ and 7A may harbor crucial salt-tolerance related loci and the linked marker could be utilized in wheat breeding for improving salt tolerance.

\section{ACKNOWLEDGEMENTS}

We are very grateful to Prof. Aimin Zhang and Dr. Dongcheng Liu for providing the genotype data of the genetic linkage map. This research was supported by the National Key Research and Development Program of China (2016YFD0300205), the National Natural Science Foundation of China (31401375) and Natural Science Foundation of Henan province (162300410133)

\section{REFERENCES}

APSE, M.P. et al. Salt tolerance conferred by overexpression of a vacuolar $\mathrm{Na}^{+} / \mathrm{H}^{+}$antiport in Arabidopsis. Science, v. 285, n. 5431, p. 1256-1258, 1999. Available from: <http://science.sciencemag. org/content/285/5431/1256.long >. Accessed: Jun. 16, 2017. doi: 10.1126/science.285.5431.1256.

ASHRAF, M. et al. Relationship between ion accumulation and growth in two spring wheat lines differing in salt tolerance at different growth stages. Journal of Agronomy and Crop Science, v. 178, n. 1, p. 39-51, 1997. Available from: <http://onlinelibrary.wiley.com/ doi/10.1111/j.1439-037X.1997.tb00349.x/full>. Accessed: Jun. 16, 2017. doi: 10.1111/j.1439-037X.1997.tb00349.x.

WANG, S. et al. Windows QTL Cartographer 2.5. Department of Statistics, North Carolina State University, Raleigh, NC. 2012. Available from: $<$ https://brcwebportal.cos.ncsu.edu/qtlcart/WQTLCart.htm>. Accessed: Jun. 18, 2017.
BOYER, J.S. Plant productivity and environment. Science, v. 218, n. 4571, p. 443-448, 1982. Available from: <http://science sciencemag.org/content/218/4571/443.long >. Accessed: Jun. 16, 2017. doi: $10.1126 /$ science. 218.4571 .443 .

CAPRIOTTI, A.L. et al. Proteomic study of a tolerant genotype of durum wheat under salt-stress conditions. Analytical and Bioanalytical Chemistry, v. 406, n. 5, p. 1423-1435, 2014. Available from: <https://dx.doi.org/10.1007/s00216-013-7549-y>. Accessed: Jun. 16, 2017. doi: 10.1007/s00216-013-7549-y.

CHEN, Y.H. et al. Ectopic expression of wheat expansin gene TaEXPA2 improved the salt tolerance of transgenic tobacco by regulating $\mathrm{Na}^{+} / \mathrm{K}^{+}$and antioxidant competence. Physiologia Plantarum, v. 159, n. 2, p. 161-177, 159, 161-177, 2017. Available from: <http://onlinelibrary.wiley.com/doi/10.1111/ppl.12492/epdf>. Accessed: Jun. 16, 2017. doi: 10.1111/ppl.12492.

CHHIPA, B.R. et al. $\mathrm{Na}^{+} / \mathrm{K}^{+}$ratios as the basis of salt tolerance in wheat. Australian Journal of Agricultural Research, v. 46, n. 3, p. 533-539, 1995. Available from: <http://www.publish.csiro.au/ AR/pdf/AR9950533>. Accessed: Jun. 16, 2017.

DUBCOVSKY, J. et al. Mapping of the $\mathrm{K}^{+} / \mathrm{Na}^{+}$discrimination locus Kna1 in wheat. Theoretical and Applied Genetics, v. 92, n. 3-4, p. 448-454, 1996. Available from: <https://link.springer.com/ article/10.1007\%2FBF00223692>. Accessed: Jun. 16, 2017. doi: $10.1007 / \mathrm{BF} 00223692$.

FEKI, K. et al. A constitutively active form of a durum wheat $\mathrm{Na}(+) / \mathrm{H}(+)$ antiporter SOS1 confers high salt tolerance to transgenic Arabidopsis. Plant Cell Reports, v. 33, n. 2, p. $277-$ 288, 2014. Available from: <https://link.springer.com/article/1 0.1007\%2Fs00299-013-1528-9>. Accessed: Jun. 16, 2017. doi: $10.1007 / \mathrm{s} 00299-013-1528-9$.

FLOWERS, T.J. et al. Breeding for salinity resistance in crop plants: where next? Australian Journal of Plant Physiology, v. 22 , n. 6 , p. $875-884,1995$. Available from: <http://www. publish.csiro.au/fp/PP9950875>. Accessed: Jun. 16, 2017. doi: org/10.1071/PP9950875.

FUKUDA, A. et al. Molecular cloning and expression of the $\mathrm{Na}^{+} / \mathrm{H}^{+}$ exchanger gene in Oryza sativa. Biochimica et Biophysica Acta, v. 1446, n. 1-2, p. 149-155, 1999. Available from: <http://www.sciencedirect. com/science/article/pii/S0167478199000652?via\%3Dihub>. Accessed: Jun. 16, 2017. doi: org/10.1016/S0167-4781(99)00065-2.

GENC, Y. et al. Sodium exclusion QTL associated with improved seedling growth in bread wheat under salinity stress. Theoretical and Applied Genetics, v. 121, n. 5, p. 877-894, 2010. Available from: <https://link.springer.com/article/10.1007\%2Fs00122-0101357-y>. Accessed: Jun. 16, 2017. doi: 10.1007/s00122-010-1357-y.

GORHAM, J. et al. Chromosomal location of a K/Na discrimination character in the D genome of wheat. Theoretical and Applied Genetics, v. 74, n. 5, p. 584-588, 1987. Available from: <https:// link.springer.com/article/10.1007\%2FBF00288856>. Accessed: Jun. 16, 2017.

GORHAM, J. et al. Partial characterization of the trait for enhanced $\mathrm{K}^{+}-\mathrm{Na}^{+}$discrimination in the $\mathrm{D}$ genome of wheat. Planta, v. 180, n. 4, p. 590-597, 1990. Available from: <https://www.researchgate. net/publication/258348558_Partial_characterization_of_the trait for enhanced K-Na discrimination in the $\mathrm{D}$ genome of wheat>. Accessed: Jun. 16, 2017. doi: 10.1007/BF02411458. 
GOYAL, E. et al. Transcriptome profiling of the salt-stress response in Triticum aestivum cv. Kharchia Local. Scientific Reports, v. 6 , n. 27752, p. 1-14, 2016. Available from: <https:/www.ncbi.nlm. nih.gov/pmc/articles/PMC4904219/>. Accessed: Jun. 16, 2017. doi: $10.1038 /$ srep27752.

GUO, G. et al. Comparative proteomic analysis of salt response proteins in seedling roots of two wheat varieties. Journal of Proteomics, v. 75, n. 6, p. 1867-1885, 2012. Available from: <http:// www.sciencedirect.com/science/article/pii/S1874391911007135>. Accessed: Jun. 16, 2017. doi: 10.1016/j.jprot.2011.12.032.

HAI, L. et al. Genomic regions for yield and yield parameters in Chinese winter wheat (Triticum aestivum L.) genotypes tested under varying environments correspond to QTL in widely different wheat materials. Plant Science, v. 175, n. 3, p. 226-232, 2008. Available from: <http://www.sciencedirect.com/science/article/pii/ S016894520800068X>. Accessed: Jun. 16, 2017. doi: 10.1016/j. plantsci.2008.03.006.

HANIN, M. et al. New insights on plant salt tolerance mechanisms and their potential use for breeding. Frontiers in Plant Science, v. 7, n. 1787, p. 1-17, 2016. Available from: <https:/www.ncbi.nlm. nih.gov/pmc/articles/PMC5126725/>. Accessed: Jun. 16, 2017. doi: $10.3389 /$ fpls.2016.01787.

HE, X. et al. A genotypic difference in primary root length is associated with the inhibitory role of transforming growth factorbeta receptor-interacting protein- 1 on root meristem size in wheat. The Plant Journal, v. 77, n. 6, p. 931-943, 2014. Available from: $<$ http://onlinelibrary.wiley.com/doi/10.1111/tpj.12449/epdf>. Accessed: Jun. 16, 2017. doi: 10.1111/tpj.12449.

HUANG, S. et al. A sodium transporter (HKT7) is a candidate for Naxl, a gene for salt tolerance in durum wheat. Plant Physiology, v. 142 , n. 4 , p. $1718-1727,2006$. Available from: <http://www. plantphysiol.org/content/142/4/1718.long>. Accessed: Jun. 16, 2017. doi: 10.1104/pp.106.088864.

JAFARI-SHABESTARI, J. et al. Field evaluation of tolerance to salinity stress in Iranian hexaploid wheat landrace accessions. Genetic Resources and Crop Evaluation, v. 42, n. 2, p. 147-156, 1995. Available from: <https://ink.springer.com/article/10.1007/ BF02539518?no-access $=$ true $>$. Accessed: Jun. 16, 2017. doi: 10.1007/BF02539518.

JIANG, Q.Y. et al. iTRAQ-based quantitative proteomic analysis of wheat roots in response to salt stress. Proteomics, v. 17, n. 8, 2017. Available from: $<$ http://onlinelibrary.wiley.com/doi/10.1002/ pmic.201600265/epdf>. Accessed: Jun. 16, 2017. doi: 10.1002/ pmic. 201600265.

KAWAURA, K. et al. Genome-wide analysis for identification of salt-responsive genes in common wheat. Functional \& Integrative Genomics, v. 8, n. 3, p. 277-286, 2008. Available from: <https:// link.springer.com/article/10.1007\%2Fs 10142-008-0076-9>. Accessed: Jun. 16, 2017. doi: 10.1007/s10142-008-0076-9.

KINGSBURY, R. et al. Selection for salt-resistant spring wheat. Crop Science, v. 24, n. 2, p. 310-315, 1984. Available from: $<$ https://eurekamag.com/research/001/249/001249769.php>. Accessed: Jun. 16, 2017. doi: 10.2135/cropsci1984.0011183X00 2400020024x.

KRISHNA, P. Brassinosteroid-mediated stress responses. Journal of Plant Growth Regulation, v. 22, n. 4, p. 289-297, 2003. Available from: $\quad<$ https://link.springer.com/article/10.1007\%2Fs00344-0030058-z>. Accessed: Jun. 16, 2017. doi: 10.1007/s00344-003-0058-z.

MAKHLOUFI, E. et al. Isolation and molecular characterization of ERF1, an ethylene response factor gene from durum wheat (Triticum turgidum L. subsp. durum), potentially involved in saltstress responses. Journal of Experimental Botany, v. 65, n. 22, p. 6359-6371, 2014. Available from: $<$ https://academic.oup.com/jxb/ article-lookup/doi/10.1093/jxb/eru352>. Accessed: Jun. 16, 2017. doi: $10.1093 / \mathrm{jxb} / \mathrm{eru} 352$.

MARTÍNEZ-ATIENZA, J. et al. Conservation of the salt overly sensitive pathway in rice. Plant Physiology, v. 143, n. 2, p. 1001-1012, 2007. Available from: <https://www.ncbi.nlm.nih.gov/pmc/articles/ PMC1803719/>. Accessed: Jun. 16, 2017. doi: 10.1104/pp.106.092635.

MASOUDI, B. et al. QTL mapping of salt tolerance traits with different effects at the seedling stage of bread wheat. Plant Molecular Biology Reporter, v. 33, n. 6, p. 1790-1803, 2015. Available from: $<$ https://link.springer.com/article/10.1007/s11105-015-0874-x>. Accessed: Jun. 16, 2017. doi: 10.1007/s11105-015-0874-x.

MEGAN, P. et al. A locus for sodium exclusion (Nax1), a trait for salt tolerance, mapped in durum wheat. Functional Plant Biology, v. 31 , n. 11, p. 1105-1114, 2004. Available from: <http://www. publish.csiro.au/fp/pdf/FP04111>. Accessed: Jun. 16, 2017. doi: 10.1071/FP04111.

MUNNS, R. Physiological processes limiting plant growth in saline soil: some dogmas and hypotheses. Plant Cell and Environment, v. 16, n. 1, p. 15-24, 1993. Available from: <http://onlinelibrary.wiley. com/doi/10.1111/j.1365-3040.1993.tb00840.x/pdf>. Accessed: Jun. 16, 2017. doi: 10.1111/ j.1365-3040.1993.tb00840.x.

MUNNS, R. et al. Approaches to increasing the salt tolerance of wheat and other cereals. Journal of Experimental Botany, v. 57, n. 5, p. 1025-1043, 2006. Available from: <https://academic.oup. com/jxb/article-lookup/doi/10.1093/jxb/erj100>. Accessed: Jun. 16, 2017. doi: $10.1093 / \mathrm{jxb} / \mathrm{erj} 100$.

OYIGA, B.C. et al. Allelic variations and differential expressions detected at quantitative trait loci for salt stress tolerance in wheat. Plant Cell and Environment. Available from: <http:// onlinelibrary.wiley.com/doi/10.1111/pce.12898/epdf>. Accessed: Jun. 16, 2017. doi: 10.1111/pce.12898.

REN, Y.Z. et al. QTLs Analysis of Wheat Seedling Traits under Salt Stress. Scientia Agricultura Sinica, v. 45, n. 14, p. 27932800, 2012a. Available from: <http://en.cnki.com.cn/Article_en/ CJFDTOTAL-ZNYK201214003.htm>. Accessed: Jun. 16, 2017. doi: 10.3864/j.issn.0578-1752.2012.14.002.

REN, Y.Z. et al. Major quantitative trait loci for seminal root morphology of wheat seedlings. Molecular Breeding, v. 30, n. 1, p. 139-148, 2012b. Available from: < https://link.springer.com/art icle/10.1007\%2Fs11032-011-9605-7>. Accessed: Jun. 16, 2017. doi: $10.1007 / \mathrm{s} 11032-011-9605-7$.

REN, Z. et al. RAS1, a quantitative trait locus for salt tolerance and ABA sensitivity in Arabidopsis. Proceedings of the National Academy of Sciences of USA, v. 107, n. 12, p. 5669-5674, 2010. Available from: <https://www.ncbi.nlm.nih.gov/pmc/articles/PMC2851765/>. Accessed: Jun. 16, 2017. doi: 10.1073/pnas.0910798107.

REN, Z.H. et al. A rice quantitative trait locus for salt tolerance encodes a sodium transporter. Nature Genetics, v. 37, n. 10, p. 
1141-1146, 2005. Available from: <https://www.nature.com/ng/ journal/v37/n10/full/ng1643.html>. Accessed: Jun. 16, 2017. doi:10.1038/ng1643.

XU, Y.F. et al. Mapping QTLs for salt tolerance with additive, epistatic and QTL $\times$ treatment interaction effects at seedling stage in wheat. Plant Breeding, v. 132, n. 3, p. 276-283, 2013. Available from: <http://onlinelibrary.wiley.com/doi/10.1111/pbr.12048/epdf $>$. Accessed: Jun. 16, 2017. doi: 10.1111/pbr.12048.

SHAHZAD, A. et al. Evaluation of wheat landrace genotypes for salinity tolerance at vegetative stage by using morphological and molecular markers. Genetics and Molecular Research, v. 11, n. 1, p. 679-692, 2012. Available from: <http://www.geneticsmr.com/articles/1557>. Accessed: Jun. 16, 2017. doi: 10.4238/2012.March.19.2.

SU, J.Y. et al. (2009) Detection of QTLs for phosphorus use efficiency in relation to agronomic performance of wheat grown under phosphorus sufficient and limited conditions. Plant Science, v. 176 , n. 2009 , p. $824-836,2009$. Available from: $<$ https://www. sciencedirect.com/science/article/pii/S0168945209000922>. Accessed: Nov. 2, 2017. doi: 10.1016/j.plantsci.2009.03.006.

SUN, W. et al. Comparative transcriptomic profiling of a salttolerant wild tomato species and a salt-sensitive tomato cultivar. Plant and Cell Physiology, v. 51, n. 6, p. 997-1006, 2010. Available from: <https://academic.oup.com/pcp/article-lookup/doi/10.1093/ pcp/pcq056>. Accessed: Jun. 16, 2017. doi: 10.1093/pcp/pcq056.

SUN, Y. et al. The wheat TaGBF1 gene is involved in the blue-light response and salt tolerance. The Plant Journal, v. 84, n. 6, p. 1219-1230, 2015. Available from: <http://onlinelibrary.wiley.com/doi/10.1111/ tpj.13082/epdf>. Accessed: Jun. 16, 2017. doi: 10.1111/tpj.13082.
TOUNSI, S. et al. Characterization of two HKT1;4 transporters from Triticum monococcum to elucidate the determinants of the wheat salt tolerance Nax1 QTL. Plant Cell and Physiology, v. 57, n. 10, p. 2047-2057, 2016. Available from: <https://academic.oup. com/pcp/article-abstract/57/10/2047/2755863/Characterizationof-Two-HKT1-4-Transporters-from>. Accessed: Jun. 16, 2017. doi: $10.1093 / \mathrm{pcp} / \mathrm{pcw} 123$.

WU, Y.Q. et al. Mapping QTL for salt tolerant traits in wheat. Journal of Nuclear Agricultural Sciences, v. 21, n. 6, p. 545549, 2007. Available from: <http://en.cnki.com.cn/Article en/ CJFDTOTAL-HNXB200706002.htm>. Accessed: Jun. 16, 2017.

ZENG, Z.B. Precision mapping of quantitative trait loci. Genetics, v. 136 , n. 4 , p. $1457-1468,1994$. Available from: <http://www. genetics.org/content/136/4/1457.long>. Accessed: Jun. 16, 2017.

ZHU, J.K. Salt and drought stress signal transduction in plants. Annual Review of Plant Biology, v. 53, n. 1, p. 247-273, 2002. Available from: <https://www.ncbi.nlm.nih.gov/pmc/articles/ PMC3128348/>. Accessed: Jun. 16, 2017. doi: 10.1146/annurev. arplant.53.091401.143329.

SAYED, H.I. Diversity of salt tolerance in a germplasm collection of wheat (Triticum spp.). Theoretical and Applied Genetics, v. 69, n. 5-6, p. 651-657, 1985. Available from: <https://link.springer. com/article/10.1007\%2FBF00251118>. Accessed: Jun. 16, 2017.

ZHU, T. et al. Ethylene and hydrogen peroxide are involved in brassinosteroid-induc -ed salt tolerance in tomato. Scientific Reports, v. 6, n. 35392, p. 1-15, 2016. Available from: <https:// www.ncbi.nlm.nih.gov/pmc/articles/PMC5064326/pdf/srep35392. pdf>. Accessed: Jun. 16, 2017. doi: 10.1038/srep35392. 